DOI: https://doi.org/10.24127/ajpm.v9i3.2869

\title{
PENGEMBANGAN MODUL STATISTIKA DESKRIPTIF BERBASIS PEMECAHAN MASALAH
}

\author{
Fitrianto Eko Subekti ${ }^{*}$, Lukmanul Akhsani ${ }^{2}$ \\ ${ }^{1 *}, 2$ Pendidikan Matematika, Universitas Muhammadiyah Purwokerto, Indonesia \\ ${ }^{*}$ Corresponding author. Jl. KH. Ahmad Dahlan, Dukuhwaluh, Purwokerto, Jawa Tengah, 53182 \\ E-mail: $\quad$ efitrians@gmail.com ${ }^{1 *)}$ \\ $\underline{\text { luk_akh@yahoo.com }}^{2}$
}

Received 16 June 2020; Received in revised form 07 September 2020; Accepted 11 September 2020

\begin{abstract}
Abstrak
Penelitian dan Pengembangan ini difokuskan untuk mengembangkan modul statistika deskriptif berbasis pemecahan masalah. Modul dikembangkan menggunakan tahapan perencanaan, perancangan, dan pengembangan yang diadopsi dari model pengembangan Thiagarajan. Modul dikatakan valid berdasarkan penilaian validator; dikatakan praktis berdasarkan hasil angket respon mahasiswa; dan dikatakan efektif berdasarkan hasil ujicoba modul berbasis pemecahan masalah. Hasil validasi menunjukkan bahwa modul memenuhi kevalidan dengan rata-rata 3,45 dari rata-rata maksimal 4,00. Hasil angket respon memenuhi kriteria kepraktisan dengan rata-rata 4,47 dari rata-rata maksimal 5,00. Sedangkan hasil tes kemampuan pemecahan masalah mahasiswa memenuhi kriteria keefektifan yang ditunjukkan dari hasil uji OneSampel t-Test bahwa pemecahan masalah mahasiswa telah mencapai KKM yang ditentukan. Berdasarkan ketiga hasil tersebut menunjukkan bahwa modul berbasis pemecahan masalah memenuhi ketiga kriteria tersebut, yaitu: valid, praktis, dan efektif.
\end{abstract}

Kata Kunci: Modul berbasis pemecahan masalah; statistika deskriptif.

\begin{abstract}
Research and development are focused on developing descriptive statistics based on problem-solving modules. Modules produced using the stages of planning, design, and development adopted from the Thiagarajan development model. Modules are said to be valid based on validator ratings. They are supposed to practice based on the results of the student response questionnaire; and assumed to be effective based on the results of the module-based problem-solving trials. The validation results show that the module meets validity with an average of 3.45 out of a maximum of 4.00. The response questionnaire's results matched the practicality criteria, with an average of 4.47 out of a maximum of 5.00. While the test results of students ' problem-solving abilities meet the effectiveness criteria shown from the results of the One-Sample t-Test that students' problem solving has reached the specified KKM. Based on the three results show that the problem-based module meets the three criteria, namely: valid, practical, and effective.
\end{abstract}

Keywords: Descriptive statistics; module based problem-solving.

This is an open access article under the Creative Commons Attribution 4.0 International License

\section{PENDAHULUAN}

Setiap jenjang pendidikan memiliki karakteristik tujuan masingmasing. Tujuan pembelajaran di Perguruan Tinggi tidak hanya transfer ilmu pengetahuan, tetapi bertujuan untuk mencari pengetahuan, menyimpulkan, dan mengimplementasi- kan pengetahuan yang diperolehnya (Alemu, S. K., 2018). Implementasi pengetahuan dibutuhkan dalam proses penyelesaian masalah. Keberhasilan perilaku seseorang, salah satunya ditentukan oleh kemampuan pemecahan masalah yang dimilikinya (Madhuri Hooda, \& Rani Devi., 2014). 
Pengetahuan awal, keterampilan tentang strategi penyelesaian masalah, dan kemampuan mengidentifikasi strategi yang mengarah kepada jawaban menjadi modal dasar dalam pemecahan masalah (Gurat, M.G., 2018). Selain itu kemampuan pemecahan masalah berpengaruh positif terhadap perilaku inovatif dan membantu mengenali peluang dalam memberikan solusi diberbagai situasi dan lingkungan yang selalu berubah (Kim, J. Y., Choi, D. S., Sung, C. S., \& Park, J. Y., 2018).

Materi statistik merupakan salah satu materi yang diajarkan disetiap jurusan di Universitas (Tishkovskaya, S., \& Lancaster, G. A., 2012). Hampir setiap jurusan memasukkan materi statistika dalam kurikulumnya. Salah satunya adalah materi statistika deskriptif. Mata kuliah ini mendasari materi statistika inferensia.

Statistika deskriptif mencakup ukuran pemusatan data, yang meliputi: mean, median, modus, dan ukuran penyebaran data, yang meliputi: rentang, variansi, standar deviasi, dan rentang interkuartil (Chan, S. W., Ismail, Z., \& Sumintono, B., 2016). Pemahaman dan penerapan statistika deskriptif dapat dilihat dari pemahaman tentang jenis data yang diperoleh, bagaimana penyajiannya, dan informasi yang diperoleh dari bentuk penyajian data yang dipilih (Marshall, G., \& Jonker, L., 2010).

Kesulitan yang muncul dalam mata kuliah statistika diantaranya: 1) kesulitan dalam membangun, menafsirkan, dan menerapkan histogram dalam konteks nyata (Zaidan, A., Ismail, Z., Yusof, Y. M., \& Kashefi, H., 2012); 2) kesulitan dalam mengklasifikasikan jenis data dan penyajian tabel atau grafik yang sesuai (Maryati, I., \& Priatna, N., 2018); dan $3)$ kurangnya pemahaman tentang makna dan ide terkait konsep ukuran penyebaran data ketika disajikan dalam bentuk grafik (Cooper, L. L., \& Shore, F. S., 2008).

Selain itu berdasarkan pengalaman dalam mengajarkan mata kuliah statistika deskriptif ada beberapa persoalan yang sering ditemui, diantaranya: 1) mahasiswa mampu menyajikan data dalam bentuk grafik, tetapi kesulitan memberikan alasan mengapa penyajian data menggunakan grafik tersebut, 2) kesulitan memaknai grafik; dan 3) kesulitan menyelesaikan masalah terkait ukuran penyebaran data.

Mata kuliah statistika deskriptif diberikan di semester I sebagai dasar untuk mata kuliah statistika inferensia. Dengan latar belakang mahasiswa dari berbagai jurusan pada saat SMA/ SMK menjadikan pemahaman awal tentang materi statistika deskriptif beragam. Selain itu mahasiswa semester I merupakan peralihan dari jenjang pendidikan sebelumnya, menjadikan mahasiswa perlu beradaptasi dan perlu didorong agar kemandirian belajarnya semakin baik..

Untuk mengatasi permasalahan tersebut perlu dikembangkan modul pembelajaran statistika deskriptif. Modul yang dikembangkan tidak hanya menekankan pada penguasaan konsep materi dan latihan soal. Tetapi modul yang memberikan pengalaman dan memberikan penekanan bagaimana mahasiswa menyelesaikan masalah terkait kehidupan sehari-hari. Pengalaman-pengalaman dalam menyelesaikan masalah menjadi bekal dalam penyelesaian masalah lain yang hampir sama atau lebih komplek Bentuk latihan yang didasarkan pada permasalahan kehidupan dan memberikan kesempatan untuk melakukan penyelidikan melalui 
penggunaan statistika yang sesuai akan memberikan pengalaman sebagai bekal dimasa yang akan datang (Libam, Z., 2010). Penggunaan modul dalam pembelajaran memfasilitasi peserta didik dalam mengembangkan kualitas belajar secara mandiri (Padmapriya, P. V., 2015).

Berdasarkan permasalahan tersebut, akan dikembangkan modul statistika deskriptif berbasis pemecahan masalah. Pada artikel ini akan dideskripsikan bagaimana pengembangan modul statistika deskriptif berbasis pemecahan masalah yang memenuhi kriteria valid, praktis, dan efektif.

\section{METODE PENELITIAN}

Penelitian dan pengembangan difokuskan pada pengembangan modul statistika deskriptif berbasis pemecahan masalah. Pengembangan modul menggunakan tiga dari empat tahapan model pengembangan Thiagarajan, yaitu: pendefinisian, perancangan, dan pengembangan (Thiagarajan, 1974). Pengembangan modul menggunakan kriteria valid, praktis, dan efektif. Data kevalidan diperoleh dari hasil validasi ahli menggunakan angket validasi. Data kepraktisan diperoleh dari hasil angket respon mahasiswa, dan data keefektifan diperoleh dari hasil tes kemampuan pemecahan masalah setelah modul berbasis pemecahan masalah diujicobakan. Berdasarkan data validasi ahli, kemudian ditentukan dengan menggunakan rumus (1):

Rata $-\operatorname{rata}(\overline{\mathrm{x}})=\frac{\text { Jumlah skor rata }- \text { rata validasi modul }}{\text { Jumlah validator }}$

Modul dikatakan valid jika minimal dalam kategori baik. Kriteria hasil validasi modul disajikan pada Tabel 1 .
Tabel 1. Kriteria hasil validasi modul

\begin{tabular}{ccc}
\hline No & Rata-rata & Kriteria \\
\hline 1. & $1,00 \leq \bar{x} \leq 1,75$ & Tidak Baik \\
\hline 2. & $1,75<\bar{x} \leq 2,50$ & $\begin{array}{c}\text { Kurang } \\
\text { Baik }\end{array}$ \\
\hline 3. & $2,50<\bar{x} \leq 3,25$ & Baik \\
\hline 4. & $3,25<\bar{x} \leq 4,00$ & Sangat Baik \\
\hline
\end{tabular}

Analisa data pada uji kepraktisan menggunakan data angket respon mahasiswa. Data angket respon ditentukan skor rata-rata, kemudian ditentukan kriterianya. Data angket respon dikatakan praktis, jika skor rataratanya $>3,40$. Kriteria hasil angket respon disajikan pada Tabel 2.

Tabel 2. Kriteria hasil angket respon mahasiswa

\begin{tabular}{ccc}
\hline No & Rata-rata & Kriteria \\
\hline 1. & $1,00 \leq \bar{x} \leq 1,80$ & Tidak Baik \\
\hline 2. & $1,80<\bar{x} \leq 2,60$ & Kurang Baik \\
\hline 3. & $2,60<\bar{x} \leq 3,40$ & Cukup Baik \\
\hline 4. & $3,40<\bar{x} \leq 4,20$ & Baik \\
\hline 5. & $4,20<\bar{x} \leq 5,00$ & Sangat Baik \\
\hline
\end{tabular}

Setelah data kevalidan dan kepraktisan diperoleh, kemudian dilakukan uji keefektifan berdasarkan hasil tes kemampuan pemecahan masalah. Data dianalisis menggunakan uji One-Sample t-Test berbantuan SPSS. Sebelum dilakukan uji tersebut, dilakukan uji normalitas data. Modul dikatakan efektif jika kemampuan pemecahan masalah mahasiswa melampaui batas atau sama dengan KKM yang ditentukan, yaitu $\geq 70.00$.

\section{HASIL DAN PEMBAHASAN}

Pengembangan modul diawali dengan tahap pendefinisian, dilanjutkan 
DOI: https://doi.org/10.24127/ajpm.v9i3.2869

perancangan dan pengembangan. Berikut gambaran hasil penelitian yang telah dilakukan dari tahap pendefinisian, perancangan, dan pengembangan.

\section{Tahap Pendefinisian}

Pada tahap pendefinisian diawali dengan observasi awal mahasiswa dimana mahasiswa yang mengikuti pembelajaran statistika deskriptif memiliki latar belakang pendidikan pada jenjang sebelumnya cukup beragam dari SMA maupun SMK dengan berbagai jurusan. Langkah selanjutnya adalah perumusan Indikator Pencapaian Kompetensi (IPK) pada mata kuliah statistika deskriptif. Indikator sebagai dasar dalam pengembangan modul statistika deskriptif berbasis pemecahan masalah. Adapun hasil dari perumusan IPK dapat dilihat pada sajiann pada Tabel 3 .

Tabel 3. Indikator Pencapaian Kompetensi Statistika Deskriptif

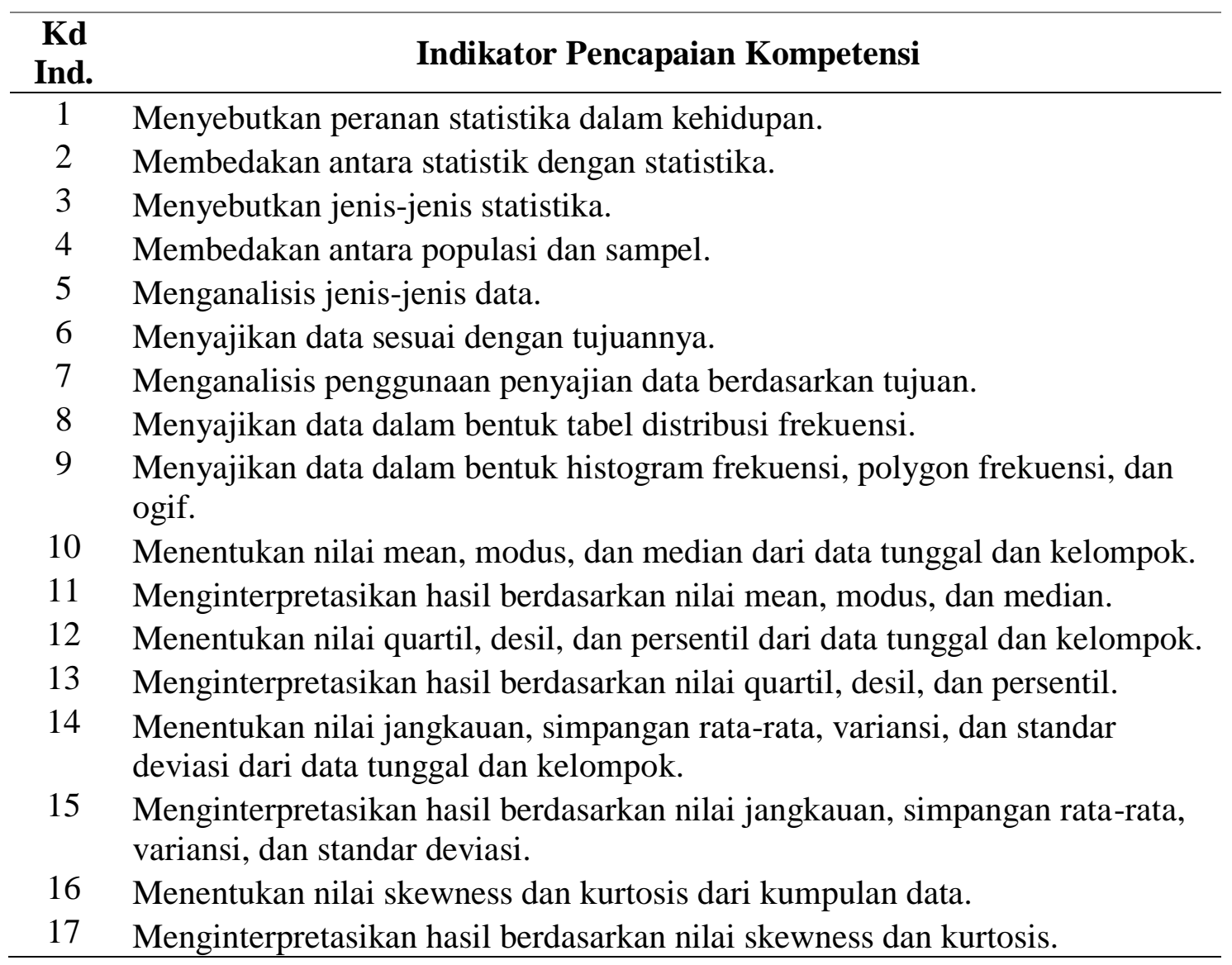

\section{Tahap Perancangan}

Pada tahap perancangan dihasilkan desain dari modul statistika deskriptif berbasis pemecahan masalah yang akan dikembangkan, lembar validasi, angket respon, dan soal tes kemampuan pemecahan masalah. Tujuh belas IPK yang dicantumkan pada
Tabel 3 digunakan untuk mendesain Kegiatan Belajar (KB) pada modul. Modul terdiri atas $7 \mathrm{~KB}$, dimana setiap $\mathrm{KB}$ terdiri atas 2 pertemuan. Pembagian indikator, $\mathrm{KB}$ dan materi statistika deskriptif secara rinci dapat dilihat pada Tabel 4. 
DOI: https://doi.org/10.24127/ajpm.v9i3.2869

Tabel 4. Kegiatan Belajar dan Materi Statistika Deskriptif

\begin{tabular}{ccc}
\hline $\begin{array}{c}\text { Indikator Pencapaian } \\
\text { Kompetensi }\end{array}$ & Kegiatan Belajar & Materi \\
\hline 1 s.d. 5 & 1 & Konsep Dasar Statistika \\
6 dan 7 & 2 & Penyajian Data \\
8 dan 9 & 3 & Tabel Distribusi Frekuensi \\
10 dan 11 & 4 & Ukuran Pemusatan Data \\
12 dan 13 & 5 & Ukuran Letak Data \\
14 dan 15 & 6 & Ukuran Penyebaran Data \\
16 dan 17 & 7 & Skewness dan Kurtosis \\
\hline
\end{tabular}

Tabel 4 yang menjelaskan tentang Kegiatan Belajar digunakan sebagai pedoman dalam pengembangan modul statistika deskriptif. Pada tahap ini dihasilkan peta konsep materi statistika deskriptif dan unsur-unsur yang ada dalam modul yang dikembangkan. Secara sederhana modul terdiri atas 2 bagian, yaitu: bagian pendahuluan dan isi. Pendahuluan berisi halaman sampul, kata pengantar dari dekan, daftar isi modul, deskripsi modul, peta konsep modul dan petunjuk penggunaan modul. Bagian isi terdiri atas $7 \mathrm{~KB}$, dimana setiap $\mathrm{KB}$ memuat tujuan, materi, dan latihan soal. Hasil akhir dari tahap perancangan adalah dihasilkannya draf modul statistika deskriptif berbasis pemecahan masalah. Pada tahap ini juga dihasilkan angket validasi, angket respon, dan soal tes kemampuan pemecahan masalah.

\section{Tahap Pengembangan}

Pada tahap pengembangan dilakukan 3 buah uji, yaitu: uji kevalidan, kepraktisan, dan keefektifan. Berikut gambaran hasil dari ketiga uji tersebut.

\section{Hasil Uji Kevalidan}

Uji kevalidan diperoleh berdasarkan penilaian validator terhadap modul yang dikembangkan.
Dari dua validator diperoleh rata-rata 3,45 , dengan rata-rata maksimal 4,00. Hasil ini menunjukkan modul memenuhi kriteria kevalidan. Beberapa saran yang diberikan oleh validator untuk perbaikan draf modul, diantaranya: 1) secara substansi dan materi sudah baik, hanya saja dibeberapa bagian terjadi kesalahan dalam penulisan; 2) peta konsep perlu ditambahkan materi variansi; 3) perlu ditambah soal-soal untuk menambah pemahaman konsep dan pemahaman secara visual; 4) penggunaan tabel perlu dikonsistenkan; 5) tambahkan ilustrasi pada gambar yang disajikan; f) tambahkan soal-soal non rutin terkait implementasi statistika dalam kehidupan; dan g) pada KB 2 perlu ditambah bagaimana menyajikan data menggunakan Microsoft Excel. Masukan-masukan tersebut dijadikan sebagai bahan untuk merevisi modul statistika deskriptif yang dikembangkan.

Pada Gambar 1, ditunjukkan tampilan modul Bab II terkait penyajian data. Setiap awal bab diawali dengan tujuan dan diakhiri dengan penugasan. Pada soal nomor 3, mahasiswa diminta menggambarkan grafik yang paling sesuai dengan tujuan dan disertai dengan alasannya. Penyajian data pada 
DOI: https://doi.org/10.24127/ajpm.v9i3.2869

soal nomor 3, mahasiswa diminta

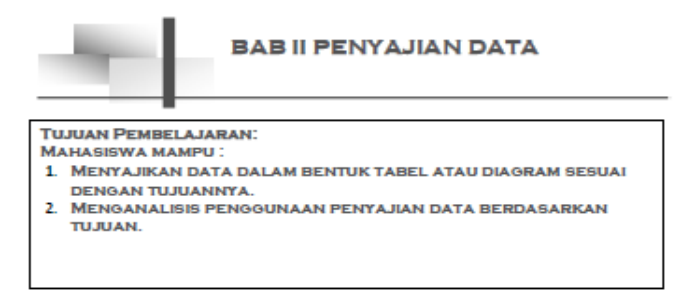

Setelah data dikumpulkan untuk kepertuan kporan dan atau analisis, data tersebut perhu disajikan Secara garis besar ada dua cara untuk menyajikan data yairu, dengan tabel dan grafili/ diagram Penyajizn data antara tabel dan grafilk saling berkaitan, karena pada dasannya sebelum membuat grafik biasanya dibuat duha tabelinya. Penyajinn data dengan bennuk grafik memudahkan seseorang untuk menggambarkan suatu keadaan. Penyajian menggunnkan grafik memiliki tujuan yang berbeda-beda. Berikut akan dijabarkan bentuk dant tujuan menyajikan data dalum bentuk tabel dan grafil.

A. Tabel

Penyajian data dalam bentuk tabel tidak bersifat kira-kira. Penyajinn dalam bentuk

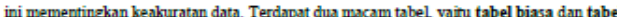
distribusi freknensi. Setiap tabel berisi judul tabel, judul setiap kolom, nilai data dahm setiap kolom, dan sumber data dari mana data tersebut diperoleh Contoh 2.1

Data jenjang pendidikan pegawai di perusahaan Berkah:

+ Bagian keuangan jumlah pegawai hùs $S 2=2$ orang, $S 1=25$ orang, sarjana muda = 90 orang, $\mathrm{SMA}=45$ orang, $\mathrm{SMK}=156$ orang: dan SMP $=12$ orang

+ Bagian Unumr jumlah pegawai yang lulus $\mathrm{S1}=5$ orang, sarjana muda $=6$ orang, SMA $=6$ orang, $\mathrm{SMK}=8$ orang, dan SMP $=4$ orang. menggunakan bantuan Microsoft excel.

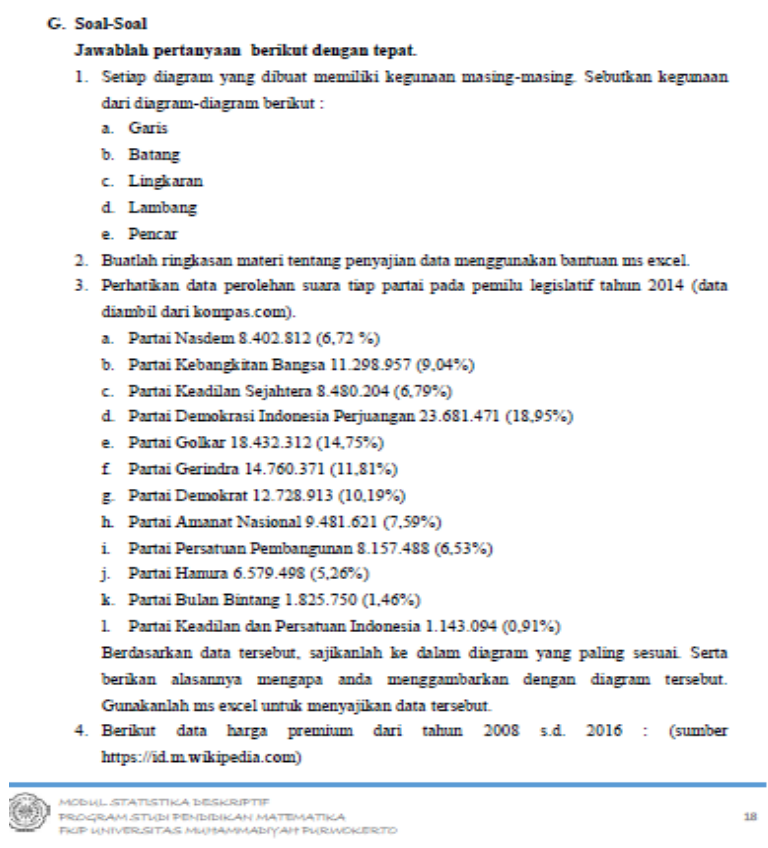

Gambar 1. Tampilan modul statistika deskriptif

\section{Hasil Uji Kepraktisan}

Data uji kepraktisan diperoleh berdasarkan hasil angket respon mahasiswa. Angket respon terdiri atas 10 pertanyaan dengan menggunakan skala Likert dengan 5 pilihan jawaban, yaitu: Sangat Setuju (SS), Setuju (S), Kurang Setuju (KS), Tidak Setuju (TS), dan Sangat Tidak Setuju (STS). Pertanyaan yang digunakan dalam angket respon mahasiswa adalah sebagai berikut: pembelajaran menggunakan modul membuat saya: 1) senang mengikutinya; 2) termotivasi berprestasi; 3) lebih dihargai; 4) lebih memahami materi; 5) lebih mudah menyelesaikan persoalan; 6) lebih percaya diri untuk terus mengembangkan diri; 7) memberikan pengalaman dan pengetahuan baru; 8) memberikan kesempatan untuk mengemukakan gagasan; 9) memberikan kesempatan bekerja secara individu maupun kelompok; dan 10) tertantang untuk terus belajar dan mengembangkan diri. Untuk lebih mudah dalam menganalisa hasil, angket disusun dalam bentuk Google Forms. Hasil angket respon mahasiswa terhadap pembelajaran menggunakan modul disajikan pada Gambar 2 .

Berdasarkan hasil angket, ratarata skor angket respon semuanya > 3,40. Dengan demikian dapat dikatakan bahwa modul yang dikembangkan memenuhi kriteria praktis. Rata-rata tertinggi terdapat pada pernyataan nomor tujuh dan sembilan, dimana pembelajaran memberikan pengalaman dan pengetahuan baru, serta memberikan kesempatan untuk bekerja baik sendiri maupun kelompok. Sedangkan rata-rata terendah terdapat pada pertanyaan nomor satu, yaitu: pembelajaran menggunakan modul membuat saya senang untuk mengikutinya. Namun secara keseluruhan berdasarkan Gambar 2 
tergambarkan hasil yang memuaskan. Pembelajaran menggunakan modul memberikan dorongan motivasi, memudahkan dalam memahami materi, dan memberikan kesempatan mengemukakan ide dan menyelesaikan masalah. Hasil angket sejalan dengan hasil tes pemecahan masalah mahasiswa.

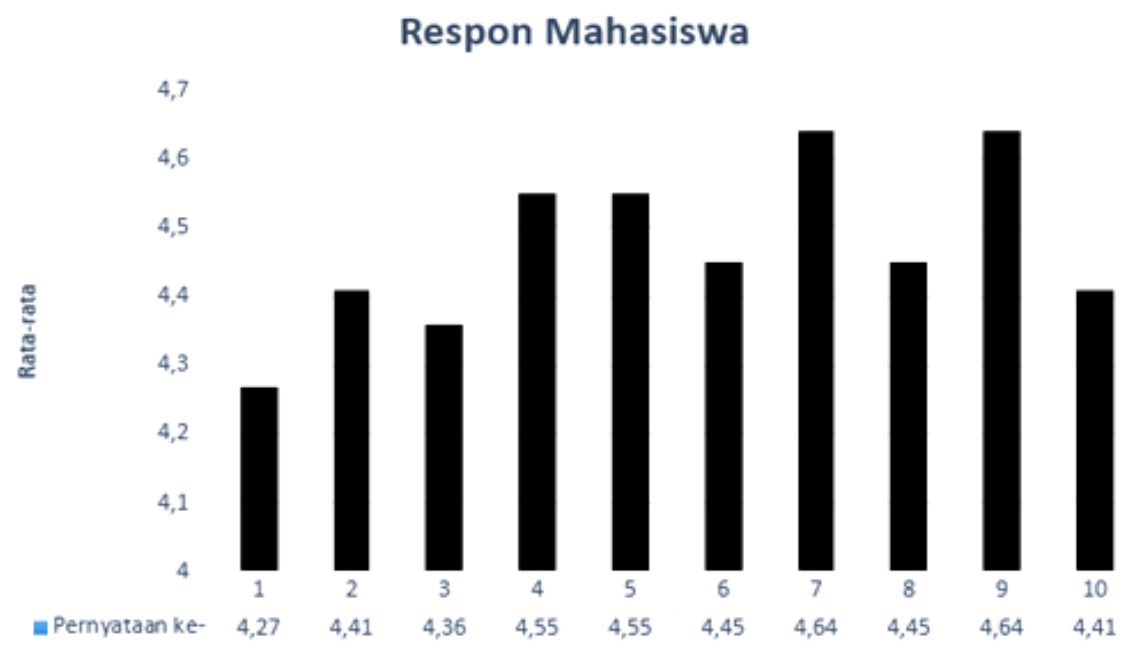

Gambar 2. Rata-rata angket respon mahasiswa

\section{Hasil Uji Keefektifan}

Data uji keefektifan diperoleh berdasarkan hasil tes setelah dilakukan ujicoba modul berbasis pemecahan masalah. Data yang dihasilkan kemudian diuji dengan menggunakan bantuan SPSS untuk mengetahui apakah data tersebut telah mencapai atau sama dengan batas ketuntasan yang ditentukan. Dalam hal ini batas ketuntasan yang digunakan adalah 70.00. Terlebih dahulu dilakukan uji normalitas data terhadap hasil tes pemecahan masalah. Tes pemecahan masalah diikuti oleh 48 mahasiswa. Uji normalitas menggunakan uji Kolmogorov-Smirnov. Berikut adalah hipotesis dari uji normalitas data.

Ho : Data pemecahan masalah berdistribusi normal

Ha : Data pemecahan masalah tidak berdistribusi normal

Ho diterima jika nilai Sig. $>\alpha$
Hasil akhir (output) dari uji normalitas data ditunjukkan pada Tabel 5. Hasil uji normalitas data diperoleh nilai Sig. = 0,116. Nilai Sig. > 0,05. Hal ini menunjukkan bahwa Ho diterima. Dengan kata lain secara statistik data pemecahan masalah berdistribusi normal.

Tabel 5. Ouput Uji Normalitas Data

\begin{tabular}{lccc}
\hline & Statistic & Df & S.ig. \\
\hline Pemecahan Masalah & .116 & 48 & $\vdots .116 ;$
\end{tabular}

Dikarenakan hasil dari uji normalitas data diperoleh kesimpulan bahwa data berdistribusi normal, maka pengujian dapat dilanjutkan ke uji OneSample t-Test karena sudah memenuhi prasyarat. Hipotesis dari pengujian OneSample t-Test adalah sebagai berikut: 
DOI: https://doi.org/10.24127/ajpm.v9i3.2869

Ho : Pemecahan masalah belum mencapai batas ketuntasan yang ditentukan $(\mu<70.00)$

Ha : Pemecahan masalah sudah melampaui atau sama dengan batas ketuntasan yang ditentukan $\alpha=0,05$ $(\mu \geq 70.00)$

Ho diterima jika nilai $1 / 2$ Sig. $>\alpha$

Tabel 6. Output hasil uji One-Sample t-Test
Selanjutnya, untuk hasil akhir (output) dari uji One-Sample t-Test yang dihitung dengan aplikasi SPSS dapat dilihat pada Tabel 6. Bagian yang menjadi inti dari hasil pengujian adalah nilai dari signifikansi atau $p$-value yang nantinya akan dibandingkan dengan taraf signifikansi atau $\alpha$.

\begin{tabular}{lcccccc} 
Test Value = 70 & \multicolumn{1}{c}{} & & \multicolumn{3}{c}{$\begin{array}{c}\text { 95\% Confidence Interval } \\
\text { of the Difference }\end{array}$} \\
\cline { 2 - 7 } & $\mathrm{T}$ & Df & $\begin{array}{c}\text { Sig. }(2- \\
\text { tailed) }\end{array}$ & $\begin{array}{c}\text { Mean } \\
\text { Difference }\end{array}$ & Lower & Upper \\
$\begin{array}{l}\text { Pemecahan } \\
\text { Masalah }\end{array}$ & 1.856 & 47 & $\begin{array}{c}: 070 \\
\vdots\end{array}$ & 4.396 & -.37 & 9.16 \\
\cline { 2 - 7 }
\end{tabular}

Pada Tabel 6 diperoleh nilai Sig. (2-tailed) $=0,070$. Karena digunakan uji satu pihak, maka nilai Sig. dibagi 2 menjadi 0,035 . Hal ini berarti nilai $1 / 2$ Sig. < 0,05, yang berarti Ho ditolak. Dengan kata lain kemampuan pemecahan masalah sudah mencapai batas ketuntasan yang ditentukan yaitu $\geq 70.00$. Dengan demikian kriteria keefektifan terpenuhi. Hal ini sejalan dengan hasil penelitian Wahab, A., Mahmud, A., \& Tiro, M. A., (2018) bahwa pembelajaran menggunakan modul efektif, dapat meningkatkan hasil belajar (Kariman, D., Harisman, Y., Sovia, A., \& Prahmana, R. C. I., 2019), dan kemampuannya lebih baik dibandingkan yang mengikuti pembelajaran tradisional (Julius, E., \& Lim, A., 2016).

Jika dilihat dari rata-rata kelas yang mengikuti pembelajaran statistika deskriptif adalah sebesar 74,40. Adapun hasil secara lengkap disajikan pada Tabel 7. Berdasarkan Tabel 7, terlihat bahwa hasil tes pemecahan masalah cukup menggembirakan, dimana diperoleh nilai mean $=74,40$, median $=$
77,50, Quartil $3=88,00$, dan nilai maksimum 95. Hal ini menunjukkan bahwa 50\% mahasiswa atau 24 mahasiswa mendapatkan nilai $\geq 77,50$ dan dari 24 mahasiswa tersebut, separohnya mendapatkan nilai $\geq 88,00$. Selain itu nilai terendahnya adalah 40,00 dan nilai tertingginya adalah 95,00 .

Tabel 7. Hasil tes pemecahan masalah

\begin{tabular}{cc}
\hline Data & Hasil \\
\hline N & 48 \\
Mean & 74,40 \\
Median & 77,50 \\
Minimum & 40,00 \\
Maksimum & 95,00 \\
Quartil 3 & 88,00 \\
\hline
\end{tabular}

Keefektifan penggunaan modul tidak terlepas dari aktivitas pembelajaran dengan menggunakan modul yang telah dilakukan. Mahasiswa terlihat aktif, termotivasi mengikuti pembelajaran, kemandirian belajarnya semakin baik, antusias untuk membaca, mendiskusikan, dan 
terdorong untuk menyelesaikan persoalan-persoalan yang disajikan dalam modul. Keaktifan mahasiswa menyelesaikan soal-soal dalam modul menjadi sebuah latihan dan pengulangan sehingga mahasiswa dapat terbiasa menyelesaikan permasalahan yang diberikan. Hal ini sejalan dengan pendapatnya Matanluk, O., Mohammad, B., Kiflee, D. N. A., \& Imbug, M. (2013) yang menyatakan bahwa penggunaan modul dalam pembelajaran mendorong minat belajar, konsentrasi, keterampilan berpikir kritis, kreatif, dan memungkinkan peserta didik mencapai hasil yang lebih baik pada saat ujian.

\section{KESIMPULAN DAN SARAN}

$\begin{array}{crr}\text { Modul } & \text { statistika } & \text { berbasis } \\ \text { pemecahan } & \text { masalah } & \text { yang }\end{array}$ dikembangkan memenuhi 3 indikator, yaitu: valid, praktis, dan efektif. Penggunaan modul dalam pembelajaran memberikan dorongan motivasi, kemandirian belajar, dan kemampuan pemahaman semakin baik. Pada penelitian ini ukuran keefektifan baru sebatas menguji ketuntasan dan belum sampai membandingkan hasil post test kelas yang mengikuti pembelajaran menggunakan modul berbasis pemecahan masalah dengan kelas kontrolnya. Harapan kedepannya modul dapat disempurnakan dan dijadikan buku pegangan dalam mata kuliah statistika deskriptif.

\section{DAFTAR PUSTAKA}

Alemu, S. K. (2018). Meaning, Idea and History of University/Higher Education: Brief Literature Review. FIRE: Forum for International Research in Education, 4(3), 210-227. DOI:10.32865/fire20184312.
Chan, S. W., Ismail, Z., \& Sumintono, B. (2016). Assessing statistical reasoning in descriptive statistics: A qualitative meta-analysis. Jurnal Teknologi, 78(6-5), 29-35. DOI:10.11113/jt.v78.8995.

Cooper, L. L., \& Shore, F. S. (2008). Students' misconceptions in interpreting center and variability of data represented via histograms and stem-and-leaf plots. Journal of Statistics Education, 16(2). DOI:10.1080/10691898.2008.1188 9559.

Gurat, M. G. (2018). Mathematical problem-solving strategies among student teachers. Journal on Efficiency and Responsibility in Education and Science, 11(3), 5364.

DOI:10.7160/eriesj.2018.110302.

Julius, E., \& Lim, A. (2016). Effectiveness of Modular Instruction in Word Problem Solving of BEED Students. IOSR Journal of Mathematics, 12(5), 2278-5728. DOI:10.9790/57281205075965.

Kariman, D., Harisman, Y., Sovia, A., \& Prahmana, R. C. I. (2019). Effectiveness of guided discoverybased module: A case study in Padang city, Indonesia. Journal on Mathematics Education, 10(2), 239-250.

Doi:10.22342/jme.10.2.6610.239250.

Kim, J. Y., Choi, D. S., Sung, C. S., \& Park, J. Y. (2018). The role of problem solving ability on innovative behavior and opportunity recognition in 
DOI: https://doi.org/10.24127/ajpm.v9i3.2869

university students. Journal of Open Innovation: Technology, Market, and Complexity, 4(1). DOI:101186/s40852-018-0085-4.

Libam, Z. (2010). Integrating real-life data analysis in teaching descriptive statistics: a constructivist approach. Journal of Statistics Education, 18(1), 1-23.

Madhuri Hooda, \& Rani Devi. (2014). Problem Solving Ability: Significance for Adolescents. Scholarly Research Journals, 2(13), 1873-1878.

Marshall, G., \& Jonker, L. (2010). An introduction to descriptive statistics: A review and practical guide. Radiography, 16(4), DOI:doi.org/10.1016/j.radi.2010.0 1.001 .

Maryati, I., \& Priatna, N. (2018). Analysis of statistical misconception in terms of statistical reasoning. Journal of Physics: Conference Series, 1013(1).

DOI:10.1088/17426596/1013/1/01 2206.

Matanluk, O., Mohammad, B., Kiflee, D. N. A., \& Imbug, M. (2013). The Effectiveness of Using Teaching Module based on Radical Constructivism toward Students Learning Process. Procedia Social and Behavioral Sciences, 90(InCULT 2012), 607-615. DOI:10.1016/j.sbspro.2013.07.132

Padmapriya, P. V. (2015). Effectiveness of Self Learning Modules on Achievement in Biology Among
Secondary School Students. International Journal of Education and Psychological Research (IJEPR), 4(2), 44-46.

Thiagarajan, (1974). Instruksional Development for Training Teachers of Exceptional Student: A Sourcebook. Miieapolis: Indiana University Bloomington.

Tishkovskaya, S., \& Lancaster, G. A. (2012). Statistical education in the 21st century: A review of challenges, teaching innovations and strategies for reform. Journal of Statistics Education, 20(2), 156.

DOI:10.1080/10691898.2012.1188 9641.

Wahab, A., Mahmud, A., \& Tiro, M. A. (2018). The effectiveness of a learning module for statistical literacy. New Educational Review, 53(3), 187-200. DOI:10.15804/tner.2018.53.3.16.

Zaidan, A., Ismail, Z., Yusof, Y. M., \& Kashefi, H. (2012). Misconceptions in Descriptive Statistics Among Postgraduates in Social Sciences. Procedia - Social and Behavioral Sciences, 46, 3535-3540.

DOI:10.1016/j.sbspro.2012.06.10. 